\title{
Urban parks and their impact on the sustainable development of the tourist area: international experience and prospects of its application in the Kaliningrad region and the Republic of Tatarstan (RF)
}

\author{
L. Semenova ${ }^{1}, O$. Bunakov ${ }^{2}$, and $L$. Puryzhova ${ }^{1}$ \\ ${ }^{1}$ Immanuel Kant Baltic Federal University, ul. Nevskogo, 14, 236041 Kaliningrad, Russia \\ ${ }^{2}$ Kazan Federal University, st. Kremlin, 18, 420008 Kazan, Rep. Tatarstan
}

\begin{abstract}
Nowadays, self-organized travel, in which a tourist without the help of travel agents forms his tour package, buying air tickets, booking hotels, transfers and other services, is becoming increasingly popular. All this became possible primarily thanks to the development of Internet services, which have recently become available and easy to use. In addition, the system of electronic payments allows you to pay for the ordered services in a short time anywhere in the world. It can be concluded that the share of independent travel will increase every year. The most popular destinations for such independent travel are national capitals and large cities with well-developed infrastructure. According to the latest research, tourists come on average for 3-4 days, stay in economy class hotels (or rented apartments), eat in authentic medium level establishments. While on holiday, they visit certain sights, such as museums, monumental buildings, nature reserves and so on. Much time is also spent walking around the city, when tourists enjoy visiting and resting in city parks. In this article, we will consider the impact of urban parks on tourism, as well as highlight the main benefits of developing the urban park environment in the context of sustainable development of the territory and attracting tourists.
\end{abstract}

\section{Introduction}

Developing a comfortable environment for a person is an urgent current task, but despite fast changes, this aspect does not receive enough attention. On the one hand, it is connected with the lack of budget funds for development [1] and underestimation of the impact of urban parks on the attractiveness and sustainable development of the territory. At the same time, many studies [2-5] show that the urban parks are of strategic importance for the development of the territory, as they positively affect the quality of life of the population. It is no coincidence that urban parks are taken as a public good [6] because even if a city park is fenced and park services are seen as consumer ones, paid by those who can afford them, it is unlikely that the fees charged will cover the direct and indirect costs (for example, for 
the personnel wages). It results in inexpediency of such a form of public goods as a city park.

Another aspect of the study relevance is the area sustainability indicators formed by many territories on the basis of Agenda 21, where among quality indicators such as water quality, air quality, transportation, etc. the issue of quality of life of the population of the territory is one of the most important.

The researchers $[7 ; 8]$ emphasize in their works that such indicators as "the number of public plantings per inhabitant", "recreation zone", "public park" are factors that can improve the quality of life and attractiveness of the destination for tourists.

\section{Urban parks for sustainable development of the destination: theoretical background}

There are several definitions of the term "park". According to S. I. Ozhegov's dictionary of the Russian language, a park is a large garden or a planted grove with alleys, flower beds, water bodies. Another point of view states that a park is an open green area intended for recreation of all visitors, which is run, as a rule, at the expense of the state [9]. The following definition is used in landscape design. A park is an extensive (usually more than 10-15 hectares) green area, landscaped and artistically designed for outdoor recreation. A forest park can be used for environmental protection purposes and its location near industrial sites or in a city contributes to air purification and has a positive impact on the environment in these areas $[10 ; 11]$.

The tradition of creating parks dates back to the Chinese civilization, and in Europe it was developed in the Baroque era. At that time, landscape parks dominated, and were accessible only to the narrow privileged sections of the population. It was only at the beginning of the 19th century that parks became more open to the public. England and France were the pioneers. The main purpose of parks at that time was to provide a place for walks and meetings (sometimes it was a place for duels). Beautification of modern megapolises with parks is not just a tribute to fashion and traditions, but a necessity [12; 13]. There comes the understanding that it is urban parks that are capable of adapting cities to climate change (abnormal heat, air pollution, rainwater drainage, etc.). Parks are becoming not only a cultural and entertainment center, but also a means to combat environmental challenges of modern megacities. One of the positive examples is Mexico City. Here it has been possible to achieve qualitative air improvement by increasing the number of green spaces [14].

In recent years, parks have become zones that offer various activities for almost any category of visitors, including tourists.

If we consider the classification of parks as green spaces, we can highlight the following (Figure 1). 


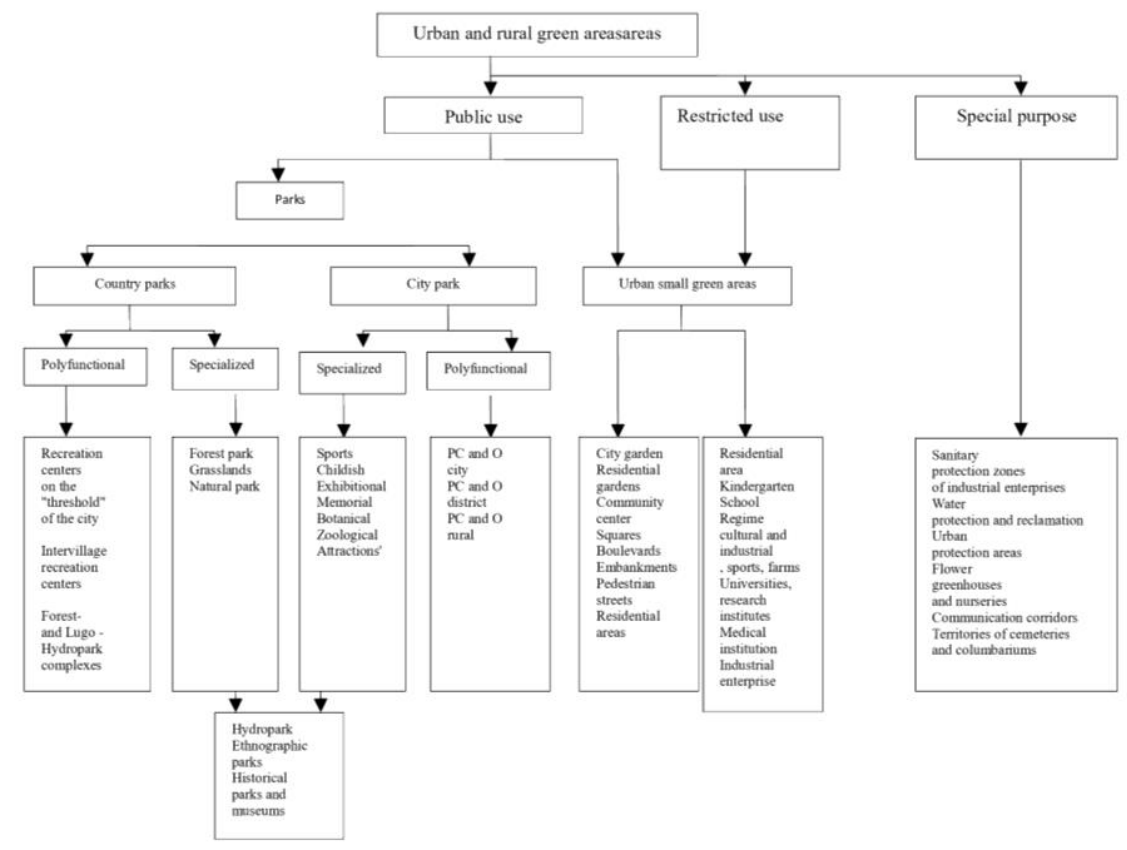

Fig. 1. Classification of green areas [7]

Another classification suggests the division of parks into an English park (landscape park); a French park (regular park); a nature park; a botanical park; an arboretum; a zoological park; a forest park; a national park; and a culture and recreation park [15]. Each type has its own specific features and objective. However, modern realities dictate the need to combine different functions and make parks often huge and multifunctional complexes. Here we should remark that almost always city parks are municipal property and are provided entirely from the city budget.

Our study focuses on multifunctional city parks for mass leisure of all age groups: they are intended primarily for pedestrians. According to the standards, the district recreational park should be at a distance of 1.5-2.0 km from dwellings, places of study, work in the city and the city park should be located within $2.0-3.0 \mathrm{~km}$; ordinary public transport (tram, bus) should be accessible within 3-4 km from the park, while high-speed (metro) transport within $6-7 \mathrm{~km}$. The time spent by the visitor on arriving at the park should not exceed 20-30 minutes. Some particular parks for certain types of recreation, educational or entertaining purposes (interest clubs, botanical and zoological parks, ethnographic parks, etc.) should be accessible by public transport running every 15-20 minutes or 1 hour or more. Leisure parks, sports parks for students are located as close as possible, considering spare time to get there, physical mobility $-0.5-0.7 \mathrm{~km}$. [16].

The recreational capacity of the territory should be considered as another important indicator of sustainable development of tourist destinations. It is the maximum number of people who can simultaneously relax within the territory without causing degradation of the biocenosis and without experiencing psychological discomfort. Both tourists and local residents impose a recreational load on the urban landscape environment, among which I identify the permissible (the number of visits per unit time per unit area, at which the stability of the natural complex is maintained, natural comfort and rational operating conditions for cultural and historical monuments are ensured) and permissible recreational load (the number of visitors per unit of recreational area (usually forest) and to the length of time, allowing for a long first time a relatively safe for the natural environment using 
natural complex for mass rest of the population). A large number of scientists are engaged in research and calculation of these indicators, and these indicators serve as the basis to work out development strategies for various territories [17].

Sustainable development of the territory, by which we mean development that ensures the satisfaction of the needs of residents and does not harm the capabilities of the future generation, is declared in the modern world as one of the basic principles of long-term strategic planning.

The World Tourism Organization (UNWTO) also deals with the sustainable development of tourism in general and individual territories in particular, and for this purpose the main goals have been formulated, among which are:

- improving the protection of natural and cultural heritage;

- improving the living standards of the local population in rural areas and areas adjacent to protected areas;

- Encouraging respect for nature and cultural heritage of tourist areas.

For example, to assess territorial development, a list of fifty indicators has been defined, which are combined into major groups. It should be noted, along with the relevance of quality indicators, such as air, soil, water, etc., the significance of the urban greenery indicator, the share of the population provided with such territories, as well as the urban biodiversity indicator are well considered. Grouped indicators characterizing the sustainability of urban development in developing countries are presented in table 1.

Table 1. 5 indicators of urban sustainability [17]

\begin{tabular}{|c|c|c|c|}
\hline Categories & Definition & Indicators & Description of the indicators \\
\hline Basic needs & $\begin{array}{l}\text { Access to safe } \\
\text { water, living } \\
\text { conditions, } \\
\text { education and } \\
\text { health services }\end{array}$ & $\begin{array}{l}\text { - Water supply } \\
\text { - Housing } \\
\text { - Health } \\
\text { - Water supply } \\
\text { - Education } \\
\end{array}$ & $\begin{array}{l}\text { - Water access rate }(\%) \\
\text { - Living space (sq.m per capita) } \\
\text { - Doctors per capita } \\
\text { - Water access rate }(\%) \\
\text { - Student teacher ratio (primary school) } \\
\end{array}$ \\
\hline $\begin{array}{l}\text { Resource } \\
\text { efficiency }\end{array}$ & $\begin{array}{l}\text { Efficient } \text { use of } \\
\text { energy, power } \\
\text { and water; waste } \\
\text { recycling }\end{array}$ & $\begin{array}{l}\text { - Power } \\
\text { - Water demand } \\
\text { - Waste recycling } \\
\text { - \% GDP from } \\
\text { heavy industry }\end{array}$ & $\begin{array}{l}\text { - Total electricity consumption (kwh per GDP) } \\
\text { - Water consumption (Liters per capita) } \\
\text { - Rate of industrial waste recycled and utilized } \\
\text { (\%) } \\
\text { - Heavy industry GDP/ Total GDP (bln RMB) }\end{array}$ \\
\hline $\begin{array}{l}\text { Environmental } \\
\text { cleanliness }\end{array}$ & \begin{tabular}{|l|} 
- Clean air and \\
water \\
- Waste \\
management
\end{tabular} & \begin{tabular}{|l|} 
- Air pollution \\
- Industrial \\
pollution \\
- Waste water \\
treatment \\
- Waste \\
management \\
\end{tabular} & $\begin{array}{l}\text { - Concentration of SOx, NOx, PM10 } \\
\text { (mg/cu.m) } \\
\text { - Industrial SO2 discharged per GDP (T/ RMB) } \\
\text { - Wastewater treatment rate (\%) } \\
\text { - Domestic waste collected \& transported } \\
(10,000 \text { T per capita) }\end{array}$ \\
\hline $\begin{array}{l}\text { Built } \\
\text { environment }\end{array}$ & \begin{tabular}{|l|} 
Dense, \\
transitoriented, \\
green, efficient \\
design
\end{tabular} & 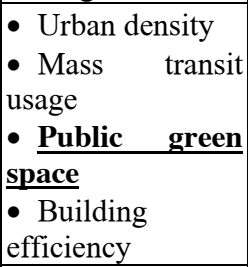 & $\begin{array}{l}\text { - Persons per square kilometer of urban area } \\
\text { - Passengers using public transit (bus, trolley) } \\
\text { - Public green space per capita (sq.m per } \\
\text { capita) } \\
\text { - Building heating efficiency }\end{array}$ \\
\hline \begin{tabular}{|l|} 
Commitment \\
to f future \\
sustainability
\end{tabular} & $\begin{array}{l}\text { Investment in } \\
\text { human and } \\
\text { physical assets }\end{array}$ & $\begin{array}{l}\text { - Green jobs } \\
\text { - Investment on } \\
\text { environmental } \\
\text { protection }\end{array}$ & $\begin{array}{l}\text { - \# of environmental professionals per capita } \\
\text { - Amount of environmental sanitation funds per } \\
\text { GDP }\end{array}$ \\
\hline
\end{tabular}


Green spaces in urban agglomerations affect not only the development of the territory itself, but also on the people living in it. So, in some authors [18; 19] note the favorable effect of nature on humans, especially in reducing stress, attention deficit disorder, as urban green areas provide people with recovery from daily tough situations. In their work, researchers built a model of the interaction between human environmental health and nature (Fig. 2).

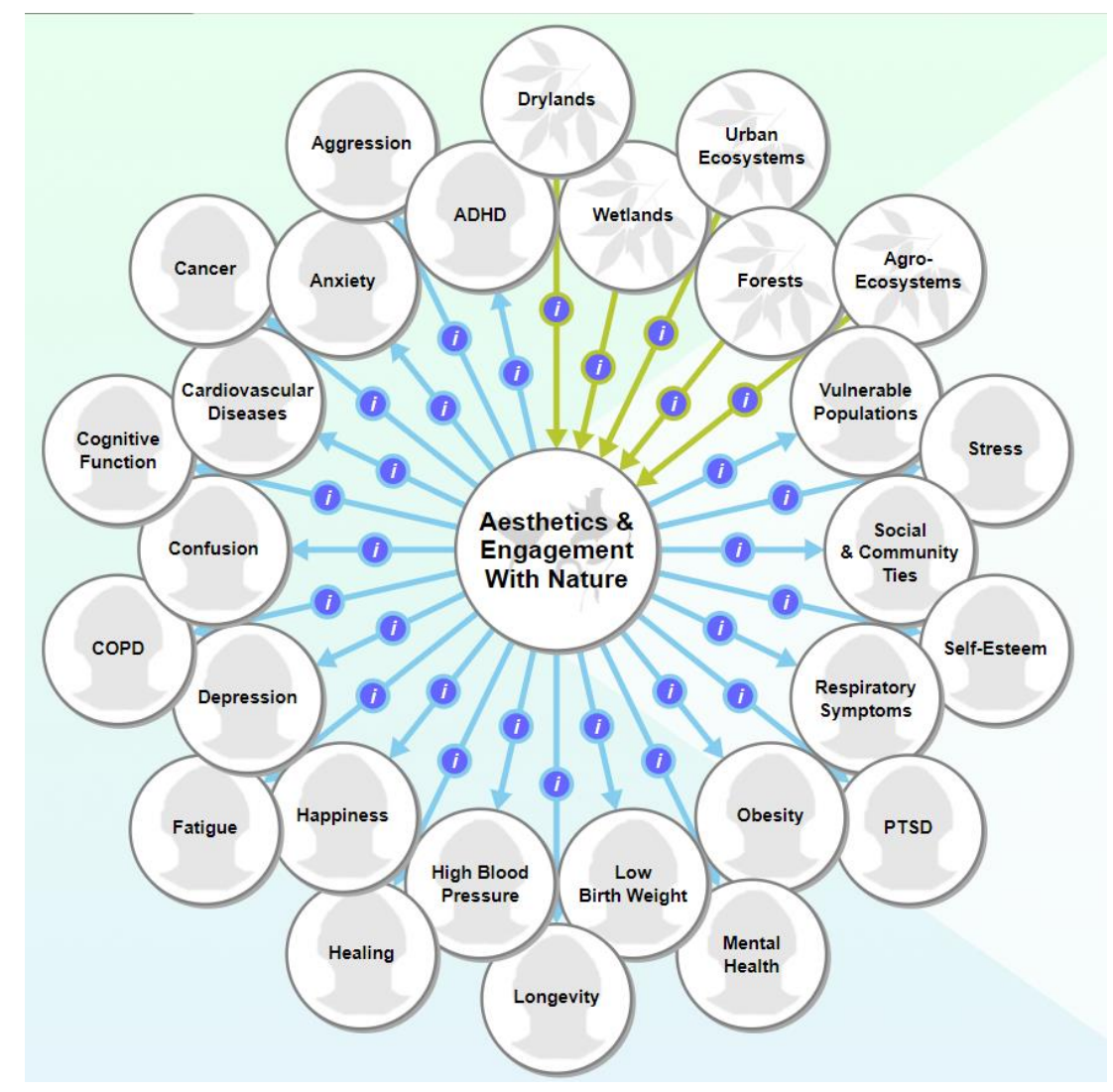

Fig. 2. Human-nature interactions: key factors

According to studies [16], exposure to natural landscapes slows down the heart rate and reduces anxiety in people. In addition, city parks facilitate communication (interaction) between people, which directly boosts social capital.

Speaking about the design of parks, it should be noted that their area and functional features can vary greatly. If desired, the park can be created even in the already existing dense urban area. The choice of the place where the park will be located in terms of communication is very important. One of the criteria for the popularity of the park is its accessibility, so when designing, you should pay attention to the routes of public transport and the proximity of highways, the presence of parking lots. The easier it is to get to the park, the greater its attendance. Proximity to popular tourist attractions will be an advantage for any park. The location of the park in the central part of the city (for example, Central Park in New York) contributes to its entry into the tourist product. The park becomes a show for tourists and a place where they spend their free time. Also, city parks attract individual travelers as a place to relax in front of some new facility. Some parks allow such tourists to put up tents and even spend the night. 
The navigation elements must be in sufficient quantities in the parks and must to quickly reach areas of interest. This will evenly distribute the load on the object and will increase visitor traffic.

\section{Research materials and methods}

In the work, we presented an overview of secondary and primary data obtained during the statistical study. The analysis used the data from the federal and municipal statistical agencies. However, unfortunately, it must be noted that not all information of interest, for example, on the number of visitors, segmentation of visitors depending on the purpose of the visit was available to us. This characterizes, in particular, the insufficient attention to this issue from state and municipal bodies, which complicates, in particular, the development of a strategy for the development of the city as a tourist destination and the formation of its attractiveness.

Studying the experience of developing city parks, one cannot ignore the world experience in organizing park spaces. The table shows the 20 largest city parks by their size.

Table 2. 20 largest parks in the world 2018 [18]

\begin{tabular}{|l|l|l|l|}
\hline Rank & Name & Location & Size in acres \\
\hline 1 & Chugach State Park & Anchorage, United States & $495,199.20$ \\
\hline 2 & Table Mountain National Park & Cape Town, South Africa & $54,610.30$ \\
\hline 3 & Pedra Branca State Park & Rio de Janeiro, Brazil & $30,626.20$ \\
\hline 4 & McDowell Sonoran Preserve & Scottsdale, United States & $30,394.00$ \\
\hline 5 & Losiny Ostrov National Park & Moscow, Russia & $28,664.20$ \\
\hline 6 & Sanjay Gandhi National Park & Mumbai, India & $25,659.40$ \\
\hline 7 & Franklin Mountains State Park & El Paso, United States & $24,246.00$ \\
\hline 8 & Bayou Sauvage National Wildlife Refuge & New Orleans, United States & $22,758.40$ \\
\hline 9 & Bukhansan National Park & Seoul, South Korea & $19,748.70$ \\
\hline 10 & Margalla Hills National Park & Islamabad, Pakistan & $17,386.00$ \\
\hline 11 & South Mountain Park & Phoenix, United States & $16,281.80$ \\
\hline 12 & Changa Manga & Lahore, Pakistan & $12,423.00$ \\
\hline 13 & Rouge National Urban Park & Toronto, Canada & $12,356.00$ \\
\hline 14 & Government Canyon State Natural Area & San Antonio, United States & $12,244.00$ \\
\hline 15 & Lee Valley Park & London, United Kingdom & $10,000.00$ \\
\hline 16 & Cullen Park & Houston, United States & $9,270.00$ \\
\hline 17 & Ulsan Grand Park & Ulsan, South Korea & $8,995.00$ \\
\hline 18 & Topanga State Park & Los Angeles, United States & $8,960.00$ \\
\hline 19 & Namhansanseong Provincial Park & Seongnam, South Korea & $8,512.80$ \\
\hline 20 & Timucuan Preserve & Jacksonville, United States & $7,870.00$ \\
\hline
\end{tabular}

The table shows that 8 of the 20 largest parks in the world are located in the United States. However, for the sake of reliability, it should be noted that in the presented rating there are national parks. Unfortunately, we could not find out individual statistics on city parks. This unfilled research field will be filled in our further research.

City and entertainment (theme) parks are highly attractive objects of a regional or urban environment. The most popular in attendance is Magic Kingdom (Walt Disney World), located in the United States (Fig. 3). In general, analyzing the presented figure, we can say that theme parks are drivers of the development of the destination. 


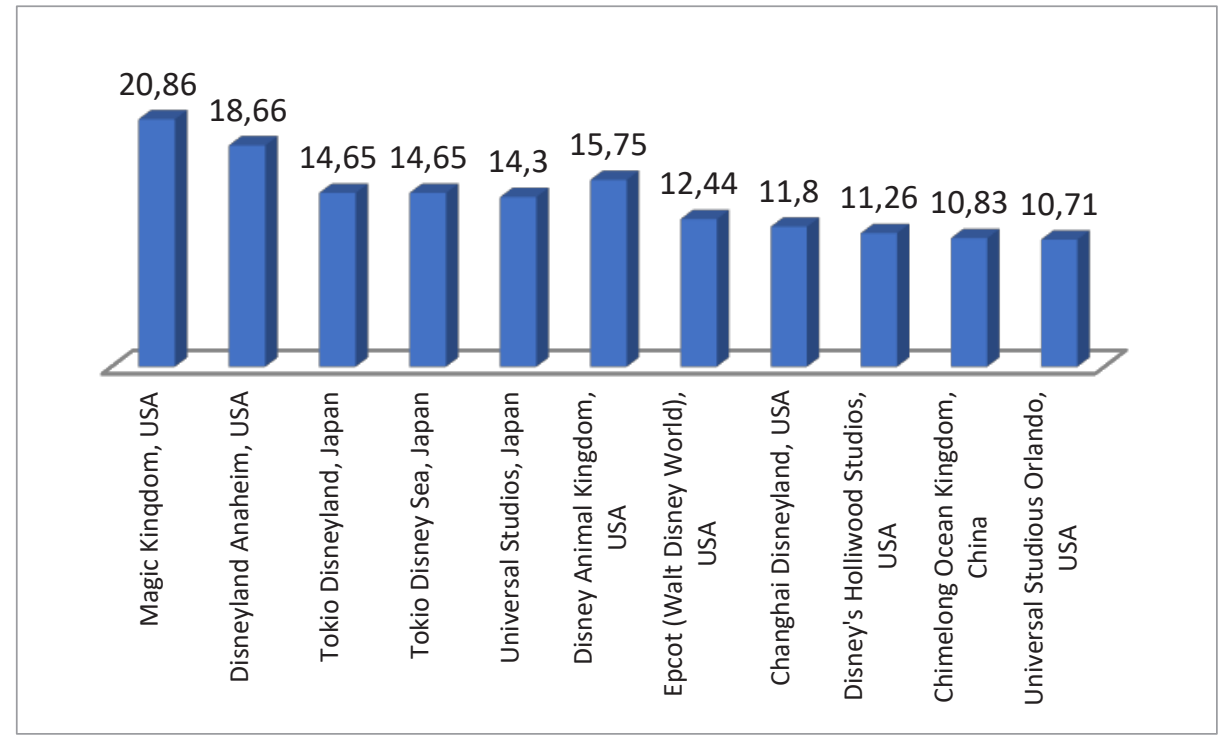

Fig. 3. Distribution of visits to amusement parks and theme parks in the world in 2018, million visitors [statista.com]

Parks provide synergetic effect on the entire urban agglomeration, as visitors to the city or theme parks buy tickets, and also use additional services, which often generate more income.

According to research by the National and Recreation Park Association (www.nrpa.org), for example, in the United States, a city park or a playground in "step-by-step availability" affects $85 \%$ of respondents' choice of property (buying a house or apartment). Currently, urban parks are an integral part of people's comfortable living and at least 7 out of 10 residents in the United States have the opportunity to visit a local urban park within walking distance of their home.

In the Russian Federation, there is also a strong focus on sustainable urban development. Let us analyze the current state and major vectors of development on the example of two areas, the Kaliningrad Region and the Republic of Tatarstan.

The Kaliningrad region is an exclave region located in the west, and has no land borders with the mainland. The total area of the region is $15125 \mathrm{~km}^{2}$.

The Republic of Tatarstan is in the center of the European part of Russia on the East European Plain, at the confluence of two rivers - the Volga and the Kama, its area is $67,836 \mathrm{~km}^{2}$.

Both regions are actively developing, as tourism is one of the priority directions of growth, it should be promising and sustainable for the territory. At the federal level a program of the Ministry of Construction and Housing and Utility Services of Russia "Formation of comfortable urban environment" in the period up to 2021was adopted in 2017, and it provides for the allocation of 500 million rubles from the federal budget and 160 million rubles from budgets of regions and municipalities for the urban parks development throughout the country. Analyzing the potential of the territories, some conclusions can be made.

The Kaliningrad region.

Due to its historical development, the Kaliningrad region has a rich heritage in territorial planning and urban development. However, it should be noted that this aspect of urban life has just recently came into the focus and now there are several programs financing the development and maintenance of urban parks in the Kaliningrad region. Thus, as of 01.01. 2018 the Kaliningrad region is the home for 79 specially protected natural territories with the total area of 67,978.8 ha, of which 1 protected area, the national park "Curonian Spit" (6,621 ha), is of federal importance and 65 protected areas are of regional importance $(61,095.2 \mathrm{ha})$, of which 52 natural sights $(1,420.8 \mathrm{ha}), 1$ natural park "Vistynetsky" (22,935 ha), 2 state natural reserves of complex (landscape) profile: State Natural Reserve "Dune" (20,798.9 ha) and State Reserve "Gromovsky" (9,967.9 ha), and 10 state nature reserves of geological profile, created to preserve the amber inclusions $(5,972.6 \mathrm{ha})$, as well as 13 
protected areas of local importance - urban recreation parks ( 82.6 ha). The highest number of urban parks is concentrated in Kaliningrad (Figure 4).

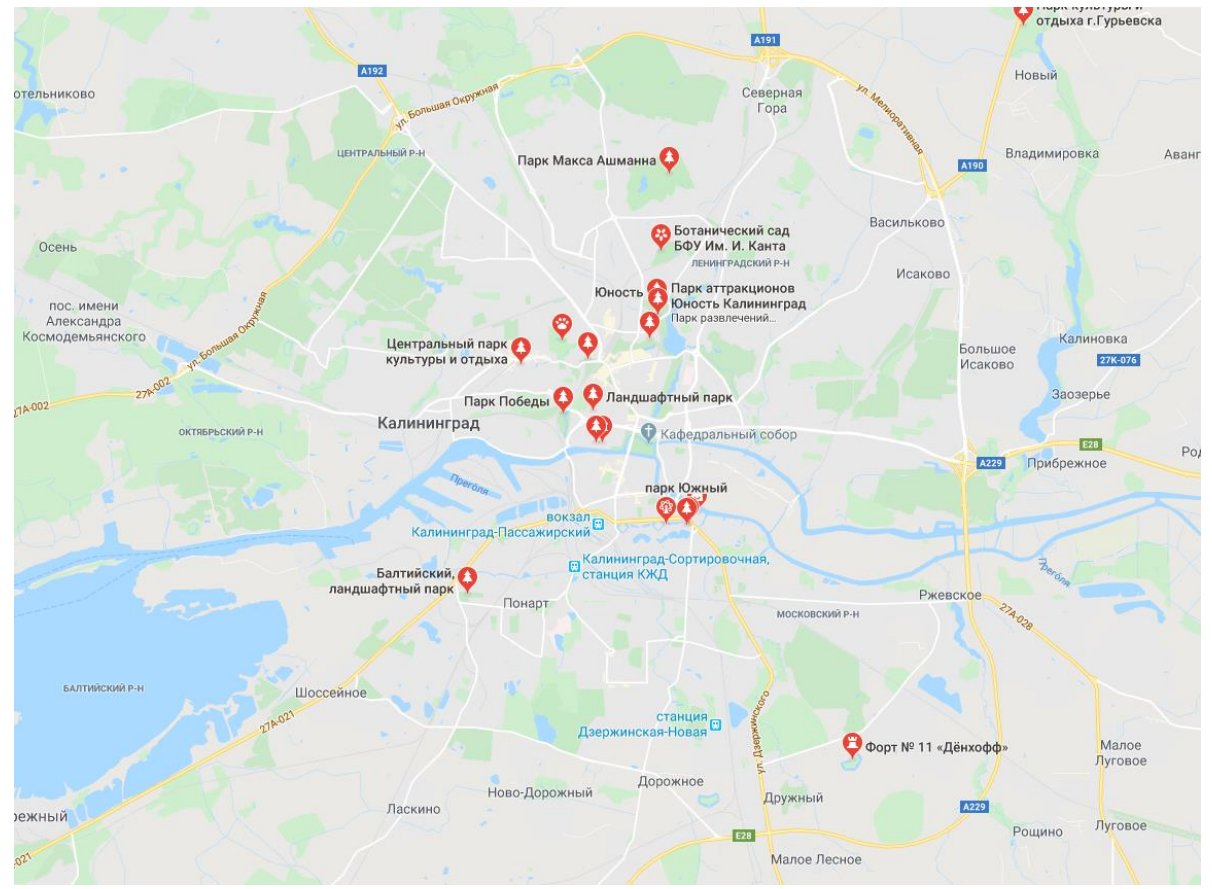

Fig. 4. Distribution of urban parks and recreation areas in Kaliningrad

Both the federal and the regional governments actively contribute to the planning and development of urban spaces. The program "Development of landscape parks of the city of Kaliningrad", adopted in December 2018, meets the interests of the urban park development in the Kaliningrad region. According to this programme, there are currently four landscape parks in Kaliningrad: Yuzhnyi, Dagestanovskyi, Yuzhnyi. Max Ashmann, Theodor Krohne, Yuri Gagarin, which is about 6.4 per cent of the total number of recreational areas in the Kaliningrad city district.

The next tool to support and stimulate the development of urban parks is the priority project "Development of a comfortable urban environment", the implementation of which is based on several basic principles. The main one is public participation. It implies that the program is discussed by architects, experts, active residents, representatives of various parties and social movements. Residents make their own choice of the yards for to be improved, discuss design projects, participate in the financing of work, coordinate reports and accept the finished work. In 2017, 12145 municipalities across the country participated in the project. 27.2 billion rubles were allocated for landscaping of parks, courtyards and public spaces. Of these, 20.5 billion came from the federal budget, the rest was allocated from the regional funds. In 2017, the Kaliningrad region spent 294.6 million rubles of budget funds on the project. Of these, 166.8 million came from federal budget funds, 98 million were the regional budget, and another 29.8 million were local budgets. In addition, in the Kaliningrad region, the financial form of participation of residents was chosen - 5\% of the cost of work (in 2017 - 11.6 million rubles) (https://minstroy39.ru/komf_sreda/).

The project provides for improving the Bagrationovsk city park. The territory of the park is to be divided into three zones: social entertainment, sports and "quiet" private zone.

In 2018, cities where landscaping will be carried out comprehensively with the involvement of the federal budget were identified. These are Guryevsk, Pionersky, Chernyakhovsk, Baltiysk and Kaliningrad. Also, with the additional financial support from the regional and local budgets, the yards in the remaining 17 municipalities will be repaired. In total, about 500 million rubles from various sources will be allocated for the project implementation, including a 5\% contribution from the owners. As a result, more than 60 inner yard territories will be improved. Work on all the facilities that were included in the project in 2017 has been completed. 


\section{The Republic of Tatarstan.}

Systematic work to improve the parks and squares of Kazan was launched back in 2011 with such programs as "Five-year health plan", "Green record" and "100 squares". It was this work that gave impetus to the development of the republican projects "Year of parks and squares" in 2015, "Year of water protection zones" in 2016, "Year of ecology and public spaces" in 2017, which ultimately grew into the federal priority project "The development of a comfortable urban environment" ".

While the projects were being implemented, in Kazan, 50 recreational sites were renovated and 20 objects were created from scratch. The total area of park areas increased by 131 hectares. Today in Kazan there are 143 parks and squares with a total area of 379 hectares.

Along with parks and squares, the city embankments are under reconstruction, in particular, the Russian-Chinese consortium Turenscape is undertaking the project of to improve the embankments of the Kaban lake system.

In 2017, another large-scale project was implemented in Kazan, i.e. eco-rehabilitation of the Lebyazhie system of lakes. Currently, the coastal zone of the lakes is being improved.

Well-groomed trees, flower arrangements and high-quality lawns have become the image of Tatarstan capital. In 2019, the flower beds covered around 22.5 thousand square meters, 3.5 thousand flower caches were planted, 11 new 3-D flower compositions were installed. "A Blossoming Kazan" project has already been implemented for several years; organizations and citizens decorate facades of buildings, adjacent and courtyard areas, palisades with flowers. As part of "A Blossoming Kazan" the "Flower Festival" is held annually from June to September at the playground in front of the children's puppet theatre "Ekiyat". Since 2012, 180 thousand trees, 155 thousand shrubs and 80 thousand perennial plants have been planted on the project "Green record".

In mid-October 2019, Kazan hosted the World Urban Parks Congress 2019 at the Kazan Expo International Exhibition Centre, where R.N.Minnikhanov, the President of the Republic of Tatarstan emphasized the undoubted importance of involving residents in the development of public space improvement projects. "One felled tree taught us that the parks and public gardens projects should be developed on the opinions of citizens, because public spaces are created for nobody else but them," the President said. We refer to the incident that happened several years ago in Kazan Uritsky's park, when contractors cut down the oldest tree while landscaping the territory, which caused a wide public outcry.

At the Congress, an agreement on the Eurasian branch of the World Urban Parks was signed, and a strategy for the development of the Kazanka River was launched. It is expected to set up 12 new parks, $54 \mathrm{~km}$ of new and renovated hiking and cycling routes and 25 places of access to the river bank within the city. In general, we can say Kazan is implementing a mega-project to create a unique park environment which enables residents and guests to move around the city without leaving the park zone. Undoubtedly, this factor will satisfy all the major prerequisites of sustainable tourism development in the territory, when public spaces are not built up, but planted and places for recreation are created.

World Urban Parks Congress has been held since 2015, the first forum was organized in Portugal. This time it invited 120 speakers, gathered more than 30 sessions and discussions. Experts from the USA, Australia, African countries, European and CIS countries were among thousands of delegates who came to Kazan.

While the issues of sustainable development of territories are supported by both federal and regional authorities, it is possible to identify the main prospects in the urban parks maintenance.

First of all, these places can provide food. Hot drinks and pastries are the most common in winter, ice cream and fast food sell well in summer. Parks are not the best location for expensive and pompous restaurants, they are ideal for the cafes where food is inexpensive and cooked quickly, can be taken away easily.

Secondly, the parks can provide equipment for rent. These can be scooters, rollers and bicycles in summer, as well as skis, sleds and mattresses in winter. In advanced places there are gazebos and places with the possibility of grilling, sun umbrellas, and many other things that can make visitors spend a long time in the park. Leasing space for business can help the authorities to become selfsufficient and sometimes even make a profit from operating the park. According to the results of 9 months of work, the parks of Kazan have brought more than 18 million rubles of income and this figure has increased almost 4 times compared to 2018 . 
Thirdly, the park areas can be used for open-air concerts, artistic gatherings, children's holidays and other public events. Often, when designing modern parks for these purposes, a special zone is allocated for a certain number of spectators and provides for some stage zone and special equipment. These rented concert venues also contribute to the municipal budget.

Finally, the parks are an area away from the city bustle, although a visitor often remains within the city limits. Then the parks must identify the zones of active and quiet time-spending, as otherwise different categories of visitors can interfere with each other's rest and deter people from visiting a certain park zone $[5,6]$.

In recent years, the construction of parks has been used as a means of managing depressed areas in major Russian cities. For example, in Kazan it was decided to build an embankment and a park near a river port. At present, this area is home to an industrial zone, as well as just green spaces. The establishment of the park will allow:

- to create a comfortable recreation area for local residents;

- to increase the attractiveness of the city for tourists coming to Kazan by water transport;

- to attract business to this area;

- to promote further development of the region.

Long established parks are also recovered and become more modern, they undergo redevelopment to ensure the equipment quality. The Directorate of Parks and Public Gardens, whose task is to design new park areas and re-equip old ones, was established in Kazan. Another task of this organization is to attract tourists to the parks. For this purpose, special routes are created (more often in the form of audio guides, as tourists are not ready to pay for such excursions), a calendar of the current events is made up. Any park requires its own "zest" to attract visitors. It may be the location of the park, the presence of a monument of nature or art, a beautiful legend, fairy tale or belief. If there is no such feature, it must be invented urgently.

Sometimes modern parks act as elements of protection of natural objects, which can be found within the city boundaries. The Lebyazhie forest park in Kazan is an example of such a strategy. The system of lakes in this park, due to the lack of any maintenance and high anthropogenic load, began to chalk quickly. However, the creation of a park changed the situation. The lakes were cleaned and useful plants planted, and paths were laid to restrict visitors' access to the most problematic areas of the park. During several years of the park's existence, the environmental situation began to improve, which shows the high role of parks in the conservation of nature objects for the population and tourists.

\section{Conclusions}

It can be concluded that at present the parks are well-integrated into the system of urban planning and efficient use of the city land. The infrastructure of parks allows different categories of visitors (including tourists) to find something to their liking and spend a long time in the park. Green spaces of parks and well-groomed water bodies allow to improve considerably the environmental situation in megacities and thereby increase the attractiveness of the territory both for local residents and visitors. The inclusion of the environmental component, business issues and the local community shows that modern urban parks can and should become the drivers of sustainable development in modern cities. The developed park network is one of the main attractions for tourists along with other city sights.

Designing a city park should include careful planning of different zones that will be interesting to different categories of visitors, and all together create a single recreation zone.

Architectural and landscape space asks for new creative approaches, unusual small architectural forms and other original elements of landscape planning, so that to make tourists excited and wishing to return while the local residents are provided with a quality place for a family rest. 


\section{References}

1. Tyrvainen, L., Vaananen Y., Landscape Urban Plan, 60, 59 (1998)

2. Alyunova, T.I., Nikolayeva, I.P., Semenova, L.V., Kiselev, S.V., Yusupova, G.F., Mayorova, A.N., Korsunova, N.M., Petrov, O.A, Journal of Sustainable Development, 8 (6), 90 (2015)

3. Mikhaylov, A. S., Baltic Region, 11(1), 29 (2019)

4. Pototskaya, T. I., Silnichaya, A. V., Baltic Region, 11(2), 112 (2019)

5. Andronache, I., Marin, M., Fischer, R., Ahammer, H., Radulovic, M., Ciobotaru, A. M., Herman, G. V., Scientific reports, 9(1), 1 (2019)

6. Samuelson P., Economics. Publisher: McGraw-Hill Education; 19th edition. (2009)

7. Beer, A.R., Urban greenspace and sustainability. In: van der Vegt, et al. (Eds.), Proceedings of a PRO/ECE-Workshop on Sustainable Urban Development: Research and Experiments, (1994)

8. Prescott-Allen, R., Caring for the Earth: A Strategy for Sustainable Living. IUCN, The World Conservation Union, United Nation Environmental Program, Worldwide Fund for Nature, (1991)

9. Ozhegov S. I., Tolkovyi slovar' russkogo yazyka, (2018)

10. Bunakov O.A, Zaitseva N.A, Larionova A.A, Ekoloji, 27(106), 441 (2018)

11. Bunakov, O.A., International Business Management, 10(21), 5104 (2016)

12. Guk T.N., Frolova Ju.V., Semenkova E.V., Blagoustrojstvo v renovacii. Podhody $i$ problemy, 268 (2018)

13. Sadeghian M., Vardanyan Z., The Benefits of Urban Parks, a Review of Urban Research. Journal of Novel Applied Sciences (2013)

14. Adiati M. P., Lestari N. S., Wiastuti R. D., IOP Conf. Series: Earth and Environmental Science 126, 012063 (2018)

15. Bulanova M. B., Ugrehelidze E. A., RSUH Bulletin. Series «Filosofija. Sociologija. Iskusstvovedenie», 96 (2015)

16. Parks. The rules of urban planning and development. The Ministry of Construction and Utility Services of the Russian Federation (2018)

17. The urban sustainability index: a new tool for measuring China's cities, Urban China Initiative, a joint initiative of Tsinghua University, Columbia University and McKinsey Company, November, 9 (2010)

18. Wolf, K.L., Housley, E., Stressed? Take a Time Out in Nature. Annapolis, MD: The TKF Foundation (2013), http://naturesacred.org/wp-content/

19. Jennings, V., Larson, L. Yun, J., International Journal of Environmental Research and Public Health, 13, 196 (2016)

20. Semenova L. V., Kropinova E. G., Dragileva I. I., Zajceva N. A., Gumenjuk I. S., Tourism development strategy in the Kaliningrad region through the cluster-based approach (2013)

21. 20 Biggest City Parks In The World, https://www.worldatlas.com/

22. UNWTO/WTCF City Tourism Performance Research (2015), http:// cf.cdn.unwto.org/ 